\title{
GAYA KEPEMIMPINAN WALIKOTA UNTUK MENINGKATKAN KINERJA DAN AKHLAK APARATUR SIPIL NEGARA DI KOTA PONTIANAK
}

\author{
Suhra Wardi \\ Fakultas Ushuludin Adab dan Dakwah IAIN Pontianak \\ Email:ssuhrawardi@gmail.com
}

\begin{abstract}
Abstrak
Gaya Kepemimpinan seseorang tidak hanya sebatas ciri yang tampak dari perilaku yang dapat di lihat oleh bawahannya akan tetapi juga akan memiliki dampak terhadap hasil kerja orang yang dipimpnnya. Setiap pemimpin memiliki gayanya masing-masing dalam melaksanakan kepemimpinannya. Dipersepsikan adanya pengaruh gaya kepemimpinan terhadap hasil kerja para aparatur karena seorang pemimpin mempengaruhi prilaku orang-orang yang dipimpinnya.Aparatur akan bersikap sesuai dengan harapan yang di inginkan oleh pemimpinnya. Bila mana pemimpinnya disiplin dalam melaksanakan tugas dan mengharapkan bawahannya juga disiplin maka ada kecenderungan terdapat sikap disiplin yang ditunjukkan oleh para aparatur.

Gaya Kepemimpinan dapat pula mempengaruhi kinerja para aparatur.Meningkat atau menurun kinerja para aparatur sangat dipengaruhi oleh pemimpinnya. Pada sisi aturan setiap aparatur sudah memiliki tugas pokoknya masing-masing, mereka semestinya taat pada tugasnya, namun pada kenyataan di lapangan masih ada aparatur yang tidak taat pada tugas pokoknya. Kinerja aparatur sangat penting untuk diperhatikan karena suksesnya program -program pemerintah sangat dipengaruhi oleh kinerja para aparatur.Pemimpin yang peduli dengan kinerja para aparaturnya akan merasakan mafaat yang besar terhadap hasil dari kepemimpinannya. Prinsip bahwa bagaiman gaya kepemimpinan seseorang akan meningkatkan kinerja aparatur dan sekaligus juga akan terjadi bertambahnya kualitas akhlak aparatur menjadi tujuan organisasi dan harapan masyarakat. Suksesnya pembangunan yang dilaksanakan pemerintah yang bertujuan untuk meningkatkan kesejahteraan masyarakat akan dapat tercapai bila mana proses pembangunan itu berjalan dengan lancar sesuai dengan perencanaan yang tentu di dukung oleh kinerja aparatur yang handal.
\end{abstract}

Kata kunci : Gaya Kepemimpinan, Kinerja, dan Akhlak

\section{PENDAHULUAN}

Gaya Kepemimpinan merupakan ciri yang dimiliki oleh para pemimpin baik di organisasi pemerintahan maupun di luar pemerintah. Di samping itu, gaya kepemimpinan juga dapat menggambarkan karakter yang dimilikinya. Pemimpin yang memiliki karakter yang tegas, cepat dan responsive akan mempengaruhi sikap para bawahannya untuk menyesuaikan dengan ciriciri karakter tersebut.Pada sisi yang lain, bilamana terdapat karakter pemimpin yang lemah dan lambat dalam pengambilan keputusan akan berpengaruh terhadap ketidaklancaran pelaksanaan programprogram pembangunan.

Walikota Pontianak periode 2014-2018 telah sukses memimpin Kota Pontianak sehingga Pontianak mengalami kemajuan yang sangat signifikan. Semasa kepemimpinannya Walikota Sutarmidji telah memperoleh 250 Piagam Penghargaan baik di tingkat Provinsi, Nasional maupun Internasional, salah satu diantaranya adalah Leadership Award dari Menteri Dalam Negeri.

Keberhasilan yang diraih oleh Pemerintah Kota Pontianak tidak terlepas dari peran Aparatur Sipil Negara (ASN). Aparatur 
Sipil Negara (ASN) Kota Pontianak bekerja sangat baik dalam melaksanakan programprogram pembangunan. Kinerja Aparatur Sipil Negara terjadi peningkatan yang lebih baik. Walikota sangat menekankan pada Aparatur Sipil Negara (ASN) untuk selalu berinovasi dalam melaksanakan pekerjaan. Melalui inovasi terjadi percepatan-percepatan pelaksanaan program pembangunan, peningkatan kualitas pelayanan publik dan peningkatan kepercayaan serta dukungan masyarakat yang semakin baik.

Walikota memberikan motivasi kepada seluruh Organisasi Perangkat Daerah (OPD) agar kreatif memunculkan inovasi-inovasi baru. Melalui kebijakan ini, Kota Pontianak berhasil memiliki 129 inovasi. Pemerintah Pusat melalui Lembaga Administrasi Negara (LAN) RI menyatakan bahwa Kota Pontianak memiliki inovasi yang paling banyak di bandingkan dengan daerah lainnya di Indonesia dan LAN menetapkan Kota Pontianak sebagai Kota Laboratorium Inovasi yang menjadi contoh bagi daerah lain untuk melakukan inovasi.

Gaya Kepemimpinan Walikota Pontianak yang menekankan pada disiplin ,tegas, taat pada aturan dan berintegritas mampu mempengaruhi Aparatur Sipil Negara(ASN) untuk meningkatkan kinerja tinggi mereka.

Dengan tulisan ini ingin diketahui bagaimana Walikota menerapkan Gaya Kepemimpinannya sehingga Kota Pontianak mencapai kemajuan yang signifikan. Tulisan ini juga mengungkapkan model penerapan disiplin pada Aparatur Sipil Negara khususnya di Pemerintah Kota Pontianak dalam melaksanakan tupoksinya masingmasing. Selebihnya, tulisan ini juga mencoba mengungkapkan hasil atau dampak dari Gaya Kepemimpinan terhadap kinerja Aparatur Sipil Negara (ASN) yang bermanfaat bagai masyarakat. Terakhir melalui tulisan ini, ingin diungkapkan keterkaitan kinerja Aparatur Sipil Negara terhadap akhlaknya sehingga tidak terjadi perilaku korup yang selama ini meresahkan masyarakat Indonesia.

Gaya Kepemimpinan memiliki pengertian sebagai suatu pola perilaku dari seorang pemimpin yang terkait dengan kompetensi nya dalam memimpin. Menurut Davis dan Newston (1995) pola tindakan pemimpin secara keseluruhan seperti yang dipersepsikan atau diacu oleh bawahan tersebut di kenal sebagai gaya kepemimpinan. Menurut Veithzal Rivai (2004) Gaya Kepemimpinan adalah pola menyeluruh dari tindakan seorang pemimpin, baik yang tampak maupun yang tidak tampak oleh bawahannya. Gaya kepemimpinan merupakan gabungan dari keterampilan, sifat dan sikap yang terdapat pada diri seseorang yang mendasari perilakunya. Gaya kepemimpinan menunjukkan baik secara langsung maupun tidak langsung keyakinan seorang pemimpin terkait dengan komptensi bawahannya. Maknanya, gaya kepemimpinan adalah perilaku dan cara seorang pemimpin sesuai dengan keterampilan ,sifat dan sikap yang dia miliki yang digunakannya untuk mempengaruhi bawahannya agar mengikuti arahannya. Sehubungan dengan kenyataan bahwa gaya kepemimpinan merupakan upaya seorang pemimpin untuk mempengaruhi bawahannya, maka Eungene Emerson et al (1992) mengemukakan enem tipe kepemimpinan Yakni: (1) kepemimpinan otokratis, (2) kepemimpinan diktator, (3) kepemimpinan demokratis, (4) kepemimpinan kharismatik, (5) kepemimpinan paternalistik, (6) kepemimpinan laissez-faire.

Masing-masing tipe kepemimpinan sebagai mana tersebut diatas tentu memiliki karakteristiknya sendiri-sendiri yang berbeda dengan dengan tipe-tipe yang lain.Banyak pendekatan untuk menganalisis tipe-tipe kepemimpinan tersebut, menurut Dr.Sudaryono (2014) cara yang digunakan untuk menganalisis tipe-tipe tersebut adalah dengan melakukan kategorisasi dari berbagai karakter itu berdasarkan: (1)Persepsi seorang pimpinan tentang peranannya selaku pimpinan; (2) Nilai-nilai yang dianut; (3) Sikap dalam mengemudikan jalannya organisasi; (4) Perilaku dalam memimpin; (5) Gaya kepemimpinan yang dominan.

Tampak dengan menggunakan pendekatan diatas ,terlihat dengan jelas bahwa tipe demokratislah yang memiliki 
karakteristik positif lebih banyak bila dibandingkan dengan tipe-tipe yang lain meskipun tipe demokratis tidak bebas dari kelemahan -kelemahan tertentu.(Sondang.P.Siagian).

Perilaku seseorang dalam melaksanakan kepemimpinan tentulah berangkat dari keyakinan bahwa untuk memelihara tujuan yang ingin diraihnya atau untuk kepentingan dirinya. Seorang pemimpin mampu menganalisis mana situasi penting dan mana situasi yang tidak penting kemudian mengambil keputusan sesuai yang menguntungkan dirinya. Akhirnya mengenai Gaya Kepemimpinan ini terkait dengan caracara yang digunakan seseorang yang disenanginya yang digunakan untuk menjalankan kepemimpinannya. Gaya Kepemimpinan seseorang kadang kala identik dengan tipe kepemimpinan orang tersebut.

Sebagian Pemerintah Daerah di Indonesia sudah memberlakukan system operasional berbasis kinerja bagi para aparaturnya. Sistem berbasis kinerja akan dapat memberikan rasa keadilan bagi para aparatur. Selama ini, sebelum menggunakan sistem berbasis kinerja, aparatur yang rajin, disiplin, taat aturan dan berintegritas merasa diperlakukan tidak adil karena gaji dan tunjangan yang diterima sama besarnya dengan mereka yang biasa -biasa saja kekantor bekerja seadanya bahkan kurang disiplin. Melalui sistem berbasis kinerja diharapkan masalah tersebut tidak akan terjadi lagi. Bagi aparatur yang bekerja dengan baik, berdedikasi dan membuat prestasi maka imbalan yang akan mereka terima lebih besar dari aparatur yang kurang dedikasinya dan tak punya prestasi kerja. Manfaat dari system berbasis kinerja ini bilamana berjalan dengan baik tentu akan menghasilkan hasil kerja berupa out put dan out come yang berkualitas. Para aparatur akan berusaha meningkatkan kualitas dan kuantitas kerja mereka guna memperoleh hasil kerja yang sesuai tujuan organisasi bahkan lebih dari yang diharapkan. Organisasi akan merasa puas karena hasil kerja para aparatur nya meningkat dan berkualitas. Kinerja organisasi ditentukan oleh kemampuan dan keterampilan segenap sumber daya yang tersedia dalam organisasi untuk secara bersama-sama mencapai tujuan organisasi. (Wibowo 2014).

Pemimpin organisasi sangat mengharapkan para aparaturnya bekerja dengan baik dan menghasilkan prestasi optimal. Sukses kepemimpinan seseorang sangat dipengaruhi oleh kinerja para aparaturnya. Kebanyakan para pemimpin berupaya agar para aparaturnya bersedia bekerja keras sehingga muncul kinerja tinggi untuk meraih prestasi organisasi. Performance management adalah mendefinisikan out puts dan aktifitas yang diharapkan, menjalankan berbagai tehnik mengukur penyelesaian outputs tersebut, dan menghargai orang atas dasar tingkat prestasinya. (Wibowo,2014).

Peran seorang pemimpin yang memberdayakan aparaturnya dalam upaya meningkatkan kemajuan organisasi secara langsung maupun tidak langsung akan berdampak pada akhlak aparaturnya. Kemajuan positif organisasi yang tentu saja di dukung oleh aparaturnya yang handal pada umumnya simetris dengan kepribadian dan akhlak aparatur. Dan Katakanlah: "Bekerjalah kamu, Maka Allah dan RasulNya serta orangorang mukmin akan melihat pekerjaanmu itu, dan kamu akan dikembalikan kepada (Allah) yang mengetahui akan yang ghaib dan yang nyata, lalu diberitakanNya kepada kaтu apa yang telah kamu kerjakan" ( Al Qur'an Surat At-Taubah Ayat 105,Juz 11. Akhlak aparatur menjadi lebih baik ketika kinerja yang diraih organisasi sesuai dengan tujuan. Pada ruang lingkup Pemerintah Daerah, misalnya,secara umum tidak ada korupsi yang dilakukkan para aparaturnya. Data menunjukkan bahwa rata-rata pemerintah daerah yang kinerjanya baik terutama yang diumumkan oleh pemerintah pusat bahwa pemerintah daerah tersebut memperoleh predikat WTP (Wajar Tanpa Pengecualian) untuk hasil pemeriksaan BPK (Badan Pemeriksa Keuangan) maka daerah yang bersangkutan minim terjadi kasus korupsi. Hal ini menunjukkan bahwa ada pengaruh pola kepemimpinan yang baik dan sukses yang disertai kinerja tinggi, maka muncul akhlak yang baik pula yang ditampilkan oleh para aparaturnya. Kota 
Pontianak memperoleh nilai yang baik terkait dengan indek persepsi korupsi. Artinya perilaku korup semakin berkurang di Kota Pontianak. Transparency International Indonesia (TII) menilai Kota Pontianak menempati posisi kedua terbaik dalam Indeks Persepsi Korupsi (IPK) dari 12 kota di Indonesia. Dalam penilaian IPK tersebut, Kota Pontianak memiliki poin 66,5 , sementara rata-rata nasional hanya 60,8. "Sesungguhnya telah ada pada (diri) Rasulullah itu suri teladan yang baik bagimu (yaitu) bagi orang yang mengharap (Rahmat) Allah dan (kedatangan) hari kiamat dan Dia banyak menyebut Allah" (Al Qur'an Surat Al-ahzab ayat 21, Juz 21).

\section{HASIL DAN PEMBAHASAN PENELITIAN}

Gaya kepemimpinan yang diterapkan oleh walikota Pontianak pada umumnya adalah Gaya Kepemimpinan demokratis disamping ada juga gaya yang lain yang menekankan pada : Disiplin aparatur, taat aturan dalam pelaksanaan pekerjaan, prima dalam pelayanan public dan aparatur yang berintegritas. Disiplin para aparatur dalam menjalankan tupoksinya (Tugas dan fungsi) masing-masing telah menghasilkan kinerja yang tinggi, baik dalam pelaksanaan program-program pembangunan yang sesuai dengan perencanaan maupun yang terkait dengan pelayanan publik. Suasana kantor pada saat - saat jam kerja, para aparatur fokus pada pekerjaannya masing-masing. Pengalaman yang terjadi misalnya, Pernah ada tamu dari luar daerah yang datang berkunjung kekantor Walikota Pontianak merasa terkesan karena menurut pengamatan mereka bahwa tidak ada aparatur yang lalu lalang/berkeluyuran atau sedang nongkrong santai di lingkungan kantor pada saat jam kerja. Pernyataan tersebut diungkapkan langsung kepada Walikota Pontianak. Pada peristiwa yang lain, Pada saat upacara harihari besar nasional, sang pemimpin selalu hadir tepat waktu bahkan sering hadir lebih awal dari aparaturnya. Beliau melarang dengan tegas aparatur yang terlambat hadir untuk ikut upacara dan dilakukan teguran kedinasan kepada yang bersangkutan. Pada masa kepemimpinannya ,walikota ini menerbitkan Perda No.10 tahun 2010 tentang larangan merokok di tempat -tempat tertentu antara lain; lingkungan kantor, sekolah, rumah sakit .

Masih terkait dengan disiplin aparatur. Walikota dalam memberikan teguran kepada aparatur yang bermasalah atau melanggar aturan beliau mengungkapkannya pada saat ada pertemuan, rapat, membuka acara kegiatan Organisasi Perangkat Daerah (OPD) dan lain-lain. Melalui cara seperti itu, aparatur lainnya dapat mengetahui masalah yang disampaikan pimpinan. Di samping membuat efek jera terhadap aparatur yang mendapat teguran di depan orang ramai karena malu, dampak dari strategi ini juga menjadi pelajaran bagi aparatur lainnya agar tidak melakukan kesalahan yang sama atau melakukan pelanggaran-pelanggaran lainnya. Pimpinan juga sering kali mengingatkan di momen pertemuan sebagaimana disebutkan diatas tadi bahwa jika ada aparatur yang melakukan pelanggaran hukum , baik hukum pidana maupun perdata dalam melaksanakan tugasnya maka pimpinan tidak akan memberikan bantuan apapun termasuk bantuan pengacara pendamping. Walikota menegaskan bahwa terkait kasus hukum , aparatur wajib mempertanggungjawabkan perbuatannya.

Perhatian pimpinan kepada para aparatur bukan hanya sebatas pada melakukan pekerjaan semata, akan tetapi juga, walikota mengamati penampilan aparatur: kerapian berpakaian, kesesuaian antara baju dan celana, cara bicara, malas atau rajin dan lainlain. Pengalaman pernah terjadi pada suatu ketika di acara apel pagi sekaligus pembagian Dipa tahun anggaran 2017 kepada kepala OPD , Terlihat oleh pimpinan ada salah satu kepala OPD tersebut memakai sepatu lusuh. Beliau langsung memberikan teguran dengan bahasa sindiran agar kepala OPD yang ditegur tersebut dapat segera mengambil sepatu di rumah jabatan walikota setelah upacara selesai. 
Pimpinan selalu melakukan kontrol terhadap pelaksanaan APBD. Secara berkala Walikota melakukan pertemuan rutin minimal sebulan sekali untuk mengevaluasi dan membahas proses berlangsungnya programprogram pembangunan yang sedang di kerjakan. Hadir dalam pertemuan evaluasi tersebut wakil walikota, sekda dan semua pejabat Eselon 2, eselon 3 , eselon 4, camat serta lurah. Walikota mengecek apa saja yang menjadi kendala dalam pelaksanaan pembangunan itu dan beliau memberikan arahan-arahan bagaimana cara mengatasi kendala - kendala yang ada. Melalui gaya kepemimpinannya yang tegas, beliau sering mengungkapkan Jika pejabat nya merasa tidak bisa melaksanakan tugasnya , silahkan mundur dari jabatannya.

Terkait Rencana APBD yang disusun oleh OPD (Organisasi Perangkat Daerah), sebelum di ajukan ke DPRD, Walikota mengecek satu demi satu setiap program yang di buat OPD. Kepala OPD yang bersangkutan di minta penjelasannya secara rinci terkait manfaat program yang dibuat untuk kesejahteraan masyarakat. Bila tidak berdampak untuk masyarakat maka beliau coret program yang diajukan itu.

Terkait dengan disiplin lalu lintas di jalan raya. Pemerintah Kota Pontianak menerapkan peraturan bahwa para pengendara dilarang memarkirkan kendaraannya di badan jalan untuk menghindari kemacetan. Aparatur Dinas Perhubungan Kota Pontianak melakukan tindakan tegas mengempeskan ban mobil jika sudah diberikan peringatan tapi masih juga belum memindahkan kendaraannya. Aparatur Dinas Perhubungan Kota Pontianak mengetahui pelanggaran ini melalui camera CCTV yang terhubung ke Pontive Centre.

Tindakan tegas juga di lakukan terhadap para pedagang kak lima yang berjualan di pinggir jalan atau trotoar yang di larang. Aparatur dari Satuan Pamong Praja Kota Pontianak melakukan peringatan penertiban dan jika tak digubris maka segera mengangkut gerobak -gerobak yang melanggar aturan tersebut untuk di amankan. Aparatur Satpol PP kota Pontianak melakukan pemantauan setiap hari di seluruh wilayah Kota Pontianak yang mereka lakukan mulai dari menjelang fajar sudah mulai bergerak.

Pelaksanaan Pembangunan Jalan di lakukan dengan membuka akses jalan baru dan melakukan pelebaran jalan yang sudah ada. Kebanyakan warga yang tanahnya terkena pelebaran jalan dengan sukarela tidak meminta ganti rugi atas tanahnya karena dengan dilebarkannya jalan maka harga tanah mereka akan semakin mahal di kawasan itu. Ganti rugi hanya akan dilakukan jika ada bangunan warga yang terkena, besaran ganti rugi sesuai dengan kesepakatan antara warga yang bersangkutan dengan Pemerintah Kota Pontianak.

Kota Pontianak adalah satu-satunya Kota di Indonesia sebagai Kota Laboratorium Inovasi. Dalam melaksanakan programprogram pembangunan selalu di lakukan inovasi-inovasi guna mempermudah layanan dan mempercepat prosesnya. Kota Pontianak memiliki 129 inovasi dan menjadi contoh bagi daerah lain dalam melaksanakan inovasi.

Capain Pemerintah Kota Pontianak yang signifikan antara lain sebagai berikut: (1) Belanja APBD Kota Pontianak periode tahun 2014-2018 setiap tahunnya mengalami peningkatan, dimana pada tahun 2014 realisasi APBD Kota Pontianak sebesar Rp.1.368.161.274.507,- dan ditargetkan meningkat menjadi Rp. 1.712.546.562.176,pada tahun 2018. Perbandingan Belanja langsung dan belanja tidak langsung juga sangat baik, dimana pada tahun 2014 porsi belanja langsung adalah 56,5\% dari APBD dan di tahun 2018 porsi belanja langsung meningkat menjadi $61,75 \%$ dari APBD. Hal ini menunjukkan kondisi APBD yang sehat, dimana alokasi belanja APBD Kota Pontianak sebagian besar ditujukan untuk kegiatan yang langsung bersentuhan dengan kepentingan masyarakat; (2) Perkembangan realisasi pendapatan daerah Kota Pontianak selama kurun waktu 4 tahun terakhir periode 20142018 terdapat peningkatan yang cukup signifikan. Pada tahun 2014 realisasi pendapatan daerah sebesar Rp.1.329.956.797.030,- dan meningkat menjadi rp.1.545.622.287.316,- pada tahun 
2017. Untuk tahun 2018 ditargetkan sebesar Rp.1.694.628.582.176,- dan sampai dengan bulan juni telah terealisasi sebesar rp.750.957.069.801,- atau 44,31\% dari target; (3) Realisasi Pendapatan Asli Daerah Kota Pontianak. Dilihat dari perkembangannya selama 4 tahun 2014-2018 secara kumulatif terdapat peningkatan yang cukup signifikan. Pada tahun 2014 jumlah pendapatan asli daerah terealisasi sebesar Rp. 298.768.480.274,- dan meningkat menjadi Rp.476.050.410.313,- pada tahun 2017. Untuk tahun 2018 ditargetkan PAD sebesar Rp.469.112.615.373,- dan sampai bulan juni terealisasi sebesar Rp.197.161.253.068,- atau sbesar 42\% dari target; (4) Analisis pencapaian pembangunan kesejahteraan masyarakat. Indikator utamanya adalah Indeks Pembangunan Manusia (IPM).IPM merupakan indikator penting untuk mengukur keberhasilan dalam upaya membangun kualitas hidup masyarakat. Secara nasional maupun Internasional, IPM dapat menentukan peringkat atau level pembangunan suatu wilayah; (5) Angka IPM terakhir yang dirilis BPS adalah IPM tahun 2017. IPM Kota Pontianak pada tahun 2017 mencapai angka 77,93. Angka IPM ini jauh meningkat dibanding capaian tahun 2013 yang baru mencapai angka 75,98. Peningkatan IPM ini di dorong oleh upaya peningkatan kualitas bidang kesehatan dan bidang pendidikan serta terjaganya kondisi makro ekonomi yang mempengaruhi daya beli masyarakat.Dengan kondisi IPM Kota Pontianak yang selalu naik dari tahun ke tahun, dapat diartikan bahwa Pembangunan Manusia di Kota Pontianak cenderung semakin baik, khususnya selama 5 tahun terakhir. IPM di bentuk oleh 3 dimensi dasar yaitu umur panjang, hidup sehat, pengetahuan dan standar hidup layak yang diterjemahkan ke dalam data statistik menjadi Angka Harapan Hidup, Angka Harapan Lama sekolah , Rata-Rata Lama Sekolah dan Pengeluaran Perkapita; (6) Secara garis besar kinerja pembangunan di bidang pendidikan menunjukkan kinerja yang baik. Hal ini tercermin dari capaian beberapa indikator bidang pendidikan yang menunjukkan peningkatan. Pada tahun 2017 Angka
Partisipasi Kasar (APK) SD mencapai 127,77\%, APK SLTP mencapai 114,82 dan APK SLTA mencapai $101,14 \%$. Sedangkan Angka Partisipasi Murni (APM) SD mencapai 107,06\%, APM SLTP mencapai 104,19\%, sedangkan APM SLTA mencapai 94,10\%. Indikator Pendidikan lainnya juga menunjukkan perkembangan yang menggembirakan seperti angka putus sekolah SLTP sebesar 0,11\% dan angka putus sekolah SLTA sebesar 0,19\%; (7) Realisasi Peningkatan kualitas pelayanan kesehatan dasar pada tahun 2017, yaitu : Angka Kematian Ibu 58,66 per 100.000 Kelahiran Hidup; Angka Kematian Bayi 3,02 per 1000 Kelahiran Hidup; Prevalensi kekurangan Gizi(Underweight) pada Anak Balita 8,59\%; (8) Prevalensi Pendek dan sangat Pendek (Stunting) pada Anak bawah dua Tahun 21,71\%; Persentase Fasilitas Kesehatan Tingkat Pertama (FKTP) yang memenuhi persyaratan sesuai standar 91,30\%; Menurunnya angka Kesakitan Penderita DBD 34,13 per 100.000; Menurunnya angka Pesakitan Penderita HIV 0,014\% Penduduk; dan Persentase Rumah Sakit di Kota Pontianak yang Terakreditasi 53,85\%. Kondisi tersebut memperlihatkan tren perbaikan di bandingkan angka tahun 2014. Angka-angka ini memperlihatkan bahwa capaian yang diperoleh sudah jauh melebihi target MDGs (Millenium Development Goal's); (9) Komunikasi antara pemerintah Daerah dengan masyarakat terus berjalan dengan intens agar partisipasi masyarakat dapat langsung di olah dan menjadi kebijakan sesuai dengan kebutuhan dan permasalahan masyarakat. Komunikasi ini dilakukan melalui penyuluhan tentang kegiatan pembangunan, dialog interaktif di media elektronik serta kerjasama publikasi dengan media cetak dan elektronik. Terakhir Kota Pontianak semakin terdepan dalam pemanfaatan teknologi informasi melalui sarana prasarana Interactive Centre (Pontive Centre) yang memiliki aplikasi GENCIL (aplikasi On line) sebagai sarana (media) informasi dan promosi daerah. Di Pontive Centre ini ada juga aplikasi E-Lawar (lapor warga), contoh: warga dapat melaporkan jalan 
berlubang menggunakan Handphone ke ELawar lalu operator akan menghubungi Dinas PU untuk memperbaikinya, setelah selesai di perbaiki jalan berlubang tersebut maka si pelapor akan di informasikan oleh operator ELawar).

Capaian-capaian tersebut di atas telah memberikan hasil berupa apresiasi dan penghargaan yang diterima oleh Pemerintah Kota Pontianak antara lain Predikat WTP (wajar Tanpa Pengecualian) dari BPK (Badan Pemeriksa Keuangan ) RI sebanyak 8 (delapan) kali berturut-turut, Nilai BB dalam penilaian Sistim Akuntabilitas Kinerja Pemerintahan (SAKIP) oleh Kemenpan RI dan Kota Pontianak telah dua kali ditetapkan oleh Ombusman RI sebagai Kota dengan Pelayanan Publik Terbaik se Indonesia. Kota Pontianak juga mendapat apresiasi dari Kementerian Dalam Negeri (Kemendagri) berupa Penghargaan atas Prestasi Kinerja status Sangat Tinggi Bintang Dua dalam penyelenggaraan Pemerintah Daerah berdasarkan Laporan Penyelenggaraan Pemerintah Daerah (LPPD) 2016 yang penilaiannya di lakukan pada tahun 2017.

Sejak tahun 2014 sampai tahun 2018 panjang jalan yang telah di kerjakan sepanjang 27.762 meter, dengan jumlah ruas jalan sebanyak 73 ruas jalan. Pembangunan Jembatan di 15 lokasi dengan volume $1.922, \mathrm{~m} 2$ dan pembangunan trotoar mencapai 25.408,47 meter yang tersebar di 36 lokasi. Pada tahun 2017 telah dimulai proses pembangunan duplikasi Jembatan Landak untuk meningkatkan aksessibilitas ke Kawasan Pontianak Utara yang saat ini sudah di pakai masyarakat. Insya Allah akan di lanjutkan dengan Pembangunan Duplikasi Jembatan Kapuas I dalam rangka meningkatkan aksessibilitas ke wilayah Pontianak Timur.

Peningkatan kualitas dan kuantitas drainase untuk mengatasi genangan air sejak tahun 2014 sampai tahun 2017 volume pembangunan saluran drainase Kota Pontianak mencapai 74.493 meter di 176 lokasi , sedangka volume pembangunan saluran drainase lingkungan mencapai 11.867 meter di 189 lokasi. Pembangunan gorong- gorong/koker mencapai 1.437 meter di 116 lokasi, pembangunan Turap/Talud dengan volume mencapai 6.274,52 meter di 55 lokasi. Sampai akhir tahun 2018, dari total 604.805 meter saluran di Kota Pontianak, pembangunan saluran drainase/goronggorong dalam kondisi baik telah terealisasi sepanjang 262.571 meter, sedangkan sisanya belum memiliki turap penahan. Kedepan secara bertahap dan dengan dukungan pembiayaan provinsi dan pusat saluran tersebut akan dipasangi turap penahan.

Pemerintah Kota Pontianak berkomitmen untuk melaksanakan pembangunan yang berkelanjutan (sustainable development). Oleh karena itu, mewujudkan tata ruang kota berwawasan lingkungan yang nyaman, aman dan layak huni menjadi prioritas untuk dilaksanakan melalui program yang berpihak pada lingkungan, dengan dilandasi ketegasan serta kepatuhan melaksanakan tata ruang. Mewujudkan penataan ruang kota yang berwawasan lingkungan dengan fokus kepada meningkatkan kualitas fisik lingkungan hidup yang lebih seimbang, meningkatkan kualitas tata ruang kota yang berwawasan lingkungan, meningkatkan pengawasan pendirian bangunan, mempercepat pemanfaatan kawasan perdagangan serta meningkatkan Taman dan Ruang Terbuka Hijau (RTH), serta yang tidak kalah pentingnya yaitu Pengendalian Ketentraman dan Ketertiban Masyarakat.

Upaya mengurangi pemukiman kumuh juga dilakukan melalui perbaikan rumah yang layak huni dan dilaksanakan melalui kemitraan antara pemerintah daerah dan kementerian perumahan rakyat. Pada tahun 2017 jumlah rumah se-kota Pontianak adalah sebanyak 149.937 unit dengan jumlah rumah tidak layak huni sebanyak 2.741 unit. Dengan bantuan perbaikan rumah tidak layak huni yang telah diberikan sebanyak 700 unit, maka jumlah rumah tidak layak huni berkurang menjadi 2.041 unit atau sekitar 1,36 persen dari total rumah se-Kota Pontianak.

Urusan penanaman modal fokus pada upaya peningkatan iklim investasi yang lebih kondusif dan layanan perijinan usaha yang cepat dan transparan. Langkah terobosan 
yang dilakukan adalah melakukan penyederhanaan prosedur perijinan, pengurangan jumlah ijin, mempercepat proses ijin serta menyediakan layanan pengurusan perijinan secara online untuk semua jenis ijin yang ada. Ini adalah bentuk aksi nyata mempermudah pelayanan kepada masyarakat khususnya, bagi para investor dalam menanamkan investasinya di Kota Pontianak.

Jumlah layanan perizinan pada BP2T Kota Pontianak sebanyak 99 jenis layanan dan terjadi penyederhanaan : (1) Tahun 20092011 disederhanakan menjadi 29 jenis layanan ; (2) Tahun 2013 disederhanakan menjadi 18 jenis layanan; (3) Tahun 2015 disederhanakan menjadi 14 jenis layanan .

\section{SIMPULAN DAN SARAN \\ Simpulan}

Gaya Kepemimpinan merupakan ciri-ciri yang dimiliki oleh seorang pemimpin sebagai cara mengelola organisasi yang dipimpinnya guna mencapai tujuan yang ingin di raihnya. Setiap Pemimpin memiliki gaya kepemimpin yang berbeda. Perbedaan gaya kepemimpinan tersebut mempengaruhi kinerja para aparaturnya. Penulis menganalisis bahwa gaya kepemimpinan yang tegas, disiplin, menekankan pada taat aturan dan mengedepankan pada integritas sukses dalam melaksanakan kepemimpinannya. Pada saat Nabi Muhammad SAW menjadi pemimpin masyarakatnya, Beliau tidak menggunakan gaya kepemimpinan yang keras dan tegas, akan tetapi Suri tauladan lah yang lebih dikedepankan namun Rasulullah sukses sebagai pemimpin waktu itu. Cakupan Wilayah Kepemimpinan Rasulullah semakin meluas dan Gaya Kepemimpinan Beliau menjadi teladan dan rujukan bagi para pemimpin di seluruh Dunia.

\section{Saran}

Berdasarkan hasil penelitian ini, peneliti menyampaikan saran-saran sebagai berikut: (1). Seorang pemimpin harus mempunyai gaya pemimpin yang tegas, disiplin, menekankan pada taat aturan dan mengedepankan pada integritas sukses dalam melaksanakan kepemimpinannya;
Pemimpin yang ingin sukses dalam melaksanakan kepemimpinannya memang harus mampu menyesuaikan dengan kondisi masyarakat yang dipimpinnya; (3) pemimpin harus mempunyai sosok cerdas.

\section{DAFTAR PUSTAKA}

Bappeda Kota Pontianak. 2018. Rancangan Peraturan Daerah Tentang Rencana Pembangunan Jangka Menengah Daerah (RPJMD) Kota Pontianak Tahun 2020-2024. Pontianak: Bappeda Kota Pontianak..

Filemon A. Uriarte,Jr. 2008. Introduction to Knowledge Management. Asean Foundation.

Gary S. Baker. Human Capital. A Theoretical and Empirical Analysis, with Special Reference to Education. The University of Chicago.

Kaswan. 2011. Pelatihan dan Pengembangan. Untuk Meningkatkan Kinerja SDM. Alfabeta Bandung.

Marwansyah. 2010. Manajemen Sumber Daya Manusia. Alfabeta Bandung.

Organisasi dan Bisnis. Unit Layanan Psikologi PKMT Press.

Pemerintah Kota Pontianak. 2018. Laporan Keterangan Pertanggungjawaban Akhir Masa Jabatan Walikota Pontianak Tahun 2014-2018. Pontianak: Pemerintah Kota Pontianak.

Pemerintah Kota Pontianak. 2018. Laporan Kinerja 2017. Pontianak: Pemerintah Kota Pontianak.

Sekretariat Daerah Kota Pontianak. Laporan Penyelenggaraan Pemerintah Daerah (LKPD) 2018.

Sudaryono. 2014. Leadership. Lentera Ilmu Cedikia.

Sue Brelade, Chris Harman. A Practical Guide To Knowledge Management.

Uzlah Maulana. 2015. Buku Smart Ayat-Ayat Al Qur'an. Cv.Tiga Mandiri.

Wahyu, Supandi. 2007. Manajeman Sumber Daya Manusia. 10 Wawasan Spektakuler dalam Menunjang Keberhasilan

Wibowo. 2011. Manajemen Perubahan. PT Raja grafindo Persada. 